mitochondria, some swelling of these organelles, and a very marked increase in the number of cristæ mitochondriales found in each organelle (Figs. 1 and 2). In addition, a number of large mitochondria of bizarre shapes were observed.

Changes in the mitochondria of liver cells of animals given thyroxin have been observed by Schulz, Löw and Sjöstrand ${ }^{2}$. They noted swelling and vacuolation of the mitochondria only. However, since the mitochondria are the site of respiratory enzymes, and since thyroxin increases cell respiration, the observations reported here provide a morphological basis for the known biochemical action of the hormone.

Pharmaceuticals Division,

G. E. Paget

J. M. THORP

Imperial Chemical Industries, Ltd.,

Alderley Park, Macclesfield.

${ }^{1}$ Reynolds, E. S., J. Cell. Biol., 17, 208 (1963).

${ }^{2}$ Schulz, H. Löw, H., Ernster, L., and Sjöstrand, F. S., Proc. Stockholm Conf. Electron Microscopy (Almqvist and Wiksell, Stockholm, 1957).

\title{
MICROBIOLOGY
}

\section{Specificity of the Solute Requirement by Marine Bacteria on Primary Isolation from Sea-water}

THE partial replacement of sodium chloride in a culture medium for a marine bacterium by sucrose or potassium chloride was recently described ${ }^{1}$. The non-specific solute requirement was shown to control the rate of growth and under the conditions of experimentation was not concerned with osmotic fragility. Some previous workers found relatively little replacement of sodium salts by other solutes and concluded that the organisms being studied had little or no osmotic requirement $\mathrm{t}^{2,3}$. In contrast, the solute requirements of the marine luminescent bacterium Photobacterium fischeri, both for growth and metabolism, were found to be non-specific and were considered to be primarily osmotic ${ }^{4,5}$. The various findings suggested the existence of species variation with respect to this property among marine bacteria. As a direct approach to a better understanding of this situation, samples of sea-water were plated directly on to media having either sodium chloride, potassium chloride, or sucrose as the principal solute. The purpose was to determine the proportion of cells in a natural inoculum which would allow a partial replacement of sodium chloride in the growth medium.

The basal medium contained 0.2 per cent trypticase ('BBL'), 0.001 M magnesium chloride, $0.005 \mathrm{M}$ potassium sulphate, 0.0005 per cent ferrous sulphate, 1 per cent Oxoid 'Ionagar No. 2'. The medium was adjusted to $p H 7$ with a few drops of $2 \mathrm{M}$ tris (hydroxymethyl) amino methane. Those media containing sucrose were supplemented with 0.2 per cent ammonium succinate to buffer the acidity possibly produced by some organisms. The solutes added are indicated in Table 1. Potassium chloride and sucrose were tested both in the presence and absence of a sub-optimal amount of sodium chloride to evaluate how frequently sodium ion could be demonstrated to be essential in a specific way to the growth of marine bacterial

Table 1. Effect of Soldtes on Colony Numbers obtarned with Marine AND FRESHWATER SAMPLES

Addition to basal medium

$\mathrm{NaCl}, 0 \cdot 35 \mathrm{M}$

$\mathrm{NaCl}, 0.025 \mathrm{M}$

$\mathrm{KCl}, 0 \cdot 35 \mathrm{M}$

KCl, 0.325 M; NaCl, $0.025 \mathrm{M}$

Sucrose, $0.5 \mathrm{M}$

sucrose, $0.5 \mathrm{M} ; \mathrm{NaCl}, 0.025 \mathrm{M}$

ro addition The values are the average number of colonies per plate; $0 \cdot 1-\mathrm{ml}$. amounts
of the marine samples were plated in triplicate; $0 \cdot 1-\mathrm{ml}$. amounts of $a$ 100-fold dilution of the pond water were plated in duplicate. The basa medium was 0.2 per cent trypticase, $0.001 \mathrm{M} \mathrm{MgCl}_{9}, 0.005 \mathrm{M} \mathrm{K}_{2} \mathrm{SO}_{4}$ and 0.0003 per cent $\mathrm{FeSO}_{4} \cdot 7 \mathrm{H}_{2} \mathrm{O}$. The media were solidified with 1.0 per cent Oxoid 'Ionagar No. 2'. species. Three samples were taken from the Atlantic Ocean at Matanzas, Florida; for a comparison, one sample was taken from a small fresh-water pond. The plates were inoculated in triplicate with $0 \cdot 1-\mathrm{ml}$. amounts; the inoculum was spread over the surface of the agar with a sterile bent glass rod. A one-hundred fold dilution of the pond water was used to give a comparable number of colonies. The cultures were incubated at $32^{\circ} \mathrm{C}$ and were observed at daily intervals through $72 \mathrm{~h}$.

The highest colony counts obtained from the marine samples occurred on the medium containing $0.35 \mathrm{M}$ sodium chloride; this contrasted with the counts from the fresh-water sample where the highest counts were obtained on the media containing the lowest amounts of salt (Table 1). The minimal level of sodium chloride required by the majority of the marine bacteria was greater than $0.025 \mathrm{M}$, which was ineffective by itself; however, approximately half the maximal number of colonies grew in media containing, in addition to $0.025 \mathrm{M}$ sodium chloride, either $0.32 \mathrm{M}$ potassium chloride or $0.5 \mathrm{M}$ sucrose. The latter solutes were much less effective in the absence of sodium chloride, indicating that for the majority of the organisms in the samples the sodium chloride could not bo completely replaced. As compared with the basal medium, a larger number of colonies grew in that to which only sucrose was added; because of the presence of a complex nutrient like trypticase, this observation cannot be considered as evidence of growth in the absence of sodium. Replicate plates made using the original plates as templates indicated that most of the organisms which responded to partial replacement of sodium ions by potas. sium chloride responded in a similar way to sucrose; a few exceptions wore observed which would accept only one or the other but not both.

The results support the view that variability occurs among marine bacteria with respect to the relative specificity of the requirement for sodium chloride and that approximately half the organisms studied would grow in media in which a substantial replacement of sodium chloride by sucrose or potassium chloride had been made.

This work was supported, in part, by the National Science Foundation grant 7075.

Darrell Prate

Department of Bacteriology,

University of Florida, Gainesville.

I Pratt, D., and Austin, M., in Symp. Marine Bacteriology (Thomas, Springfleld, Ill.) (in the press).

MacLeod, R. A., and Onofrey, E., J. Cellular Comp. Physiol., 50, 380 (1957).

${ }^{3}$ Payne, J., J. Bacteriology, 80, 696 (1960).

${ }^{4} J o h n s o n$, F. H., and Harvey, E. N., J. Cellular Comp. Physiol., 11, 213 (1938).

${ }^{5}$ McElroy, W. D., in The Bacteria, 2, 479 (Academic Press, New York and London, i96i).

\section{Effect of Mycobacterium tuberculosis H37Rv grown in vivo (LH37Rv) on Ehrlich Carcinoma Ascites Cells}

Previous reports from this laboratory have shown that cells of Mycobacterium tuberculosis H37Rv separated from lungs of mice infected with this strain are coated with nicotinamide adenine nucleosidase (NADase) of the host ${ }^{1}$. Discussing the possible role of NADase adsorbed by the tubercle bacilli in the pathogenesis of tuberculosis, we havo assumed that, on phagocytosis of tubercle bacilli, the nicotinamide adenine dinucleotide splitting enzyme may impair the electron transport system of the phagocyte, thus bringing about the death of the lattor ${ }^{2}$. It should be recalled that a similar hypothesis was propounded by Bernheimer et $a l .^{3}$, who found a remarkable correlation between the capacity of stroptococci to produce extracellular NADase and leukotoxicity. The authors sugges. ted that the leukotoxicity might woll be due to the dostruction of NAD of the phagocytizing cell by streptococcal 